\title{
I, Sex Robot: the health implications of the sex robot industry
}

\author{
Chantal Cox-George, ${ }^{1}$ Susan Bewley ${ }^{2}$
}

${ }^{1}$ St George's University Hospitals NHS Foundation Trust, London, UK

${ }^{2}$ Women's Health Academic Centre, King's College London, London, UK

\section{Correspondence to}

Dr Chantal Cox-George, St George's University Hospitals NHS Foundation Trust, London SW17 0QT, UK; ccoxgeorge@ gmail.com

Received 25 October 2017 Revised 6 April 2018

Accepted 8 April 2018 Published Online First 4 June 2018
Check for updates

To cite: Cox-George C, Bewley S. BMJ Sex Reprod Health 2018;44:161-164.

\section{INTRODUCTION}

The sex technology industry is already estimated to be worth US\$30 billion. ${ }^{1}$ While sex toys are well-established, sex robots ('sexbots'), anthropomorphic devices created for sexual gratification, are no longer science fiction. Four companies sell adult sexbots priced between US\$5000 and US $\$ 15000$. They must be distinguished from 'paedobots' - childlike robotic models at present only produced by one company. ${ }^{2}$ The market appears to be men, and so far only 'female' adult sexbots have been created, although one company reports aiming to sell 'male' devices later in $2018 .^{3}$ Sex robots are realistic mannequins with variable ages, appearances and textures, and customisable oral, vaginal and anal openings.

The medical profession needs to be prepared for inevitable questions about the impact of sex robots on health. Apart from free-market profits, the majority of arguments in their favour use 'harm limitation' somewhat defensively to convince others that this is one way to protect the vulnerable. Opponents reject the hypothesis that they reduce sexual crimes, and instead raise concerns about the potential for harm by further promoting the pervasive idea that living women too are sex objects that should be constantly available - 'misogynistic objectification' - and intensifying existing physical and sexual violence against women and children.

What characterises all discussions of this issue is the paucity of an evidence base. This might falsely reassure clinicians not to concern themselves with changing their current clinical practice. However, an absence of evidence does not excuse the medical profession from discussing and debating the issues, as there will inevitably be consequences for physical, mental and social well-being.

\section{METHODOLOGY}

We aim to provide a succinct summary of the arguments for and against the sex robot industry and to assess the potential health implications that may affect both patients and clinicians. To find information about the health consequences of sex robot use a narrative literature review via PubMed and Google was conducted, using the terms 'robot', 'sex', 'sex toys', 'doll', 'child sex abuse', 'sex therapy', 'paedophile*' with follow-up of embedded references, and informal discussions with expert informants from various specialties. In order to explore the themes identified, we considered sexbots within the contexts of pornography, sex dolls and virtual reality.

We found no reports of primary data relating to health aspects of the use of sex robots.

\section{THEMES IDENTIFIED}

We identified four key themes relevant to healthcare providers:

- Safer sex

- Therapeutic potential

- Potential to treat paedophiles and sex offenders

- Changing societal norms.

\section{Do sex robots promote safer sex?}

Some people envision a future with no sex trafficking, sex tourism or sex trade. One hypothetical future red-light district has been described where the spread of sexually transmitted infections is prevented by providing robotic prostitutes made of bacteria-resistant fibre, flushed for human fluids after use. ${ }^{4}$ This well-intentioned scenario is optimistic, and sexbots can already be bought, or leased for parties. There may be legal liability ramifications should the engineering of sexbots fail, leading to injury or infection, and with unclear responsibility for condoms and cleaning protocols. ${ }^{5}$ 
Third-party interests, witnesses and bystander effects have to be considered as sexbots enter the public domain. Greater tolerance of sexbots relies on society having an informed and agreed view of a laissez-faire governmental approach, rather than one regulating financial exchanges related to sexual activity. This chimes with present disputes about 'full' versus 'limited' decriminalisation of prostitution, which the British Medical Association recently rejected for want of good evidence of sex workers' health and safety protection. ${ }^{6}$ It is speculative whether the development of a sexbot marketplace will lead to lesser risk of violence and infections, or drive further exploitation of human sex workers. Sexual violence survivors and activists already campaign against "rape culture" - the idea that (overwhelmingly) male violence is regarded as entitled and prosecution is so difficult that perpetrators of sexual abuse act with impunity.

\section{Do sex robots have therapeutic value?}

Psychosexual therapists should examine the future impact of sex robots on empathy and human relationships. It is at least plausible that sex robots will be helpful for patients who would benefit from sexual practice without pressure, although this might move some further away from human intimacy. Sexual activity with robots has been described as a masturbatory practice, so someone with sexual dysfunction, which may already lead to isolation, "might become even more isolated by the illusion of having a substitute satisfaction". ${ }^{8}$ Psychosexual therapists might use sexbots to assist couples with mismatched libido or to help treat erectile dysfunction, ${ }^{9}$ but potential adverse consequences, such as rejection of the non-interacting partner or threats to the integrity of the relationship, are underplayed. Sexbots might provide 'companionship' for the lonely, mentally and physically disabled, the elderly, or those who find intercourse traumatic, ${ }^{9}$ though this justification requires a change in meaning of 'companion' from a living, interacting person. It also seems patronising to argue for a 'lesser' sexual experience when most people with disabilities can form mutually satisfying relationships. Artificial intelligence means sexbots will move, eye-track, 'speak' and simulate sexual functions as they "adapt to their user's needs and even moods" ${ }^{2}$ However, it remains unproven that intimacy 'needs' will be satisfied: there could be worsened distress. ${ }^{10}$ While a human may genuinely desire a sexbot, reciprocation can only be artificially mimicked.

\section{Do sex robots have potential to treat paedophiles and sex offenders?}

Even before sexbots, there was little consensus on the impact of pornography, although there are claims of an association with reduced incidences of rape and prostitution, confounded by causality, transparency and recognition that there are conflicts of interest.
Countervailing risks have been expressed including commodifying human beings, normalising sexual deviancy, becoming 'addictive', acting as a practice ground for violence, and promoting the control of vulnerable individuals. ${ }^{11}$ While many sexbot users may distinguish between fact and fantasy, some buyers may not, leading to concern about potentially exacerbating the risk of sexual assault and rape of actual children and adults.

Virtual reality has been shown to evoke realistic (and potentially gratifying) responses in sexually deviant and non-deviant men in controlled research settings. ${ }^{12}$ One company (with a decade's experience producing life-like child sex dolls) claims that they help individuals "redirect dark desires", ${ }^{12}$ thus protecting potential victims. The company's chief executive officer, a man with self-confessed paedophilic impulses, ${ }^{13}$ believes that aberrant sexual desires cannot be remedied but instead should be expressed legally and ethically, otherwise life would not be "worth living". ${ }^{14}$ This might be taken literally or seen as a manipulative suicide threat.

In the USA, virtual child pornography is considered legally distinct from imagery involving real children. ${ }^{15}$ In the UK, it would not be illegal to own a child sexbot, although a man has been jailed for "importing an obscene article", a child sex doll. ${ }^{16}$ Forensic physicians working in Sexual Assault Referral Centres have been involved in police investigations of customs offences, providing age assessment of child sex dolls (size, age-related features, Tanner staging, hair, clothing) (L O'Connor, ME Vooijs, S Lewis, C White, K Shardlow, BP Butler, personal communications, 2017).

Given present major weaknesses in the evidence base, and the lack of evidence of effective treatments of sexual offenders against children, we would strongly caution against the use of paedobotsas putative 'treatment' unless as part of robust, scientifically and ethically acceptable research trials.

\section{Will there be changes in societal norms?}

Sexbots are generally female and 'air-brushed', raising the question of public interest in avoiding gender discrimination and inequality due to the promotion of distorted views of attractiveness that reduce female body confidence. There are worries about blurred boundaries to consent ${ }^{17}$ and permission for enacted violence when sexbot 'personalities' can be selected that simulate non-consensual sex - that is, rape. The Foundation for Responsible Robotics states that the sex between human and robot is intrinsically different to sex between humans because "machinery ... cannot grant consent or be raped"18 But can the user's motivation be entirely discounted? An established UK judgement determined that consent does not protect against charges of unlawful and malicious wounding and assault occasioning actual bodily harm. ${ }^{19}$

If therapeutic benefit were demonstrated, would doctors 'prescribe' sexbots based on 'harm reduction', 
and how would onward use be controlled? ${ }^{12}$ It would not be surprising if some doctors had conscientious objections based on feeling professionally or morally compromised. Even if sexbots 'worked' and contributed to health, the products' high cost would presumably limit accessibility.

\section{CONCLUSIONS}

Evidence-based healthcare is at the core of medical professionalism and practice. The current dearth of information on health aspects of sexbots may relate to rapid commercial innovation, low sales, few direct consultations, failure to recognise and report health and social consequences for patients, or inadequate investment in research.

However, absent evidence of efficacy of both therapeutic value and sexual satisfaction will hardly dampen market forces. Potential profits and rising demand will incentivise companies to produce cheaper sexbots. Technological advances will drive competition to create the most affordable but desirable model. Research has explored 'robotiquette' for the management of humanrobot interactions. ${ }^{20}$ We call for more research in this sphere. Future health studies might include medical observations, case reports, and measurement of visual and neural responses of users, alongside evidence of the impact of robots, and sexbots in particular, in the education, criminal justice and social science sectors.

The UK General Medical Council and medical defence organisations have not issued any guidance, but doctors might be advised to avoid using sexbots themselves, given police interest, prosecutions, and the potential negative impact on public trust.

The overwhelmingly predominant market for sexbots will be unrelated to healthcare. Thus the 'health' arguments made for their benefits, as with so many advertised products, are rather specious. Currently, the 'precautionary principle' should reject the clinical use of sexbots until their postulated benefits, namely 'harm limitation' and 'therapy', have been tested empirically.

Acknowledgements The authors wish to thank the many colleagues who offered insights but who withheld their names out of discretion.

Contributors CCG is an Academic Foundation Year 2 Doctor at St George's Hospital in London with interests in sexual and reproductive health. She researched and drafted the article. SB is Professor of Women's Health at King's College London. She advised and edited the article. Both authors approved the final version.

Funding The authors have not declared a specific grant for this research from any funding agency in the public, commercial or not-for-profit sectors.

Competing interests None declared.

Patient consent Not required.

Provenance and peer review Not commissioned; externally peer reviewed.

Data sharing statement No additional data available.
(C) Article author(s) (or their employer(s) unless otherwise stated in the text of the article) 2018. All rights reserved. No commercial use is permitted unless otherwise expressly granted.

\section{REFERENCES}

1 Kleeman J. The race to build the world's first sex robot. The Guardian [online]. https://www.theguardian.com/technology/ 2017/apr/27/race-to-build-world- first-sex-robot (accessed 25 Aug 2017).

2 Torjesen I. Sixty seconds on...sex with robots. BMJ 2017;358:j3353.

3 Ramos J. Realistic male sex robots with bionic penises will go on sale this year. Science Trends [online]. https://sciencetrends. com/realistic-male-sex- robots-bionic-penises-will-go-sale-year/ (accessed 25 Jan 2018).

4 Yeoman I, Mars M. Robots, men and sex tourism. Futures 2012;44:365-71.

5 Siddique HG. Sex robots promise 'revolutionary' service but also risks, says study. The Guardian [online]. 2017 https://www. theguardian.com/technology/2017/jul/05/sex-robots-promiserevolutionary-service-but-also-risks-says-study (accessed 25 Aug 2017).

6 Nordicmodelnow.org [online]. BMA rejects motion 422 to decriminalise sex trade. https://nordicmodelnow.org/2017/ 07/06/bma-rejects-motion-422-to- decriminalise-sex-trade/ (accessed 13 Sep 2017).

7 Ellis P. \#WomenNotObjects: how advertisers can help put a stop to rape culture in 2017. Huffington Post [online]. http:// www.huffingtonpost.co.uk/philip- ellis/womennotobjects-howadver_b_13604388.html (accessed 13 Sep 2017).

8 Facchin F, Barbara G, Cigoli V. Sex robots: the irreplaceable value of humanity. BMJ 2017;358:j3790.

9 Kerner I. What the sex robots will teach us. CNN [online]. http://edition.cnn.com/2016/12/01/health/robot-sex-futuretechnosexuality/index.html (accessed 5 Sep 2017).

10 Bendel O. Surgical, therapeutic, nursing and sex robots in machine and information ethics. In: van Rysewyk S, Pontier M, eds. Machine medical ethics. Intelligent systems, control and automation: science and engineering: Springer, 2015;74:17-32.

11 Richardson K. The asymmetrical 'relationship': parallels between prostitution and the development of sex robots. SIGCAS Computers \& Society [online] 2015 https://campaign againstsexrobots.org/the-asymmetrical-relationship-parallelsbetween-prostitution-and-the-development-of-sex-robots/ (accessed 5 Oct 2017).

12 Rutkin A. Could sex robots and virtual reality treat paedophilia? New Scientist [online]. https://www.newscientist. com/article/2099607-could-sex- robots-and-virtual-realitytreat-paedophilia/ (accessed 25 Aug 2017).

13 Can Child Dolls Keep Pedophiles from Offending? https:// www.theatlantic.com/health/archive/2016/01/can-child-dollskeep-pedophiles-from-offending/423324/.

14 Osborne S. Japanese company manufactures lifelike child sex dolls for paedophiles. The Independent [online]. 2016 http://www.independent.co.uk/news/world/asia/japanesecompany-manufactures-lifelike-child-sex-dolls-for-paedophilesa6811046.html (accessed 1 Sep 2017).

15 Stout D. Supreme court strikes down ban on virtual child pornography. The New York Times [online]. http://www. nytimes.com/2002/04/16/national/supreme-court-strikes-downban-on-virtual-child-pornography.html (accessed 06 Oct 2017).

16 Day $\mathrm{H}$. Nuclear energy consultant, 49, who smuggled a $£ 150$ 'paedophile' sex doll resembling a four-year-old girl into the UK is 


\section{Editorial}

jailed for two years in landmark case. Daily Mail [online]. http:// www.dailymail.co.uk/news/article-4633322/Man-smuggledpaedophile-sex-doll-jailed.html (accessed 13 Sep 2017).

17 Thames Valley Police. Tea and consent. 2015 https://www. youtube.com/watch?v=pZwvrxVavnQ (accessed 14 Sep 2017).

18 Sharkey N, van Wynsberghe A, Robbins S, et al. Our sexual future with robots. Foundation for Responsible Robotics [online]. 2017
http://responsiblerobotics.org/wp-content/uploads/2017/07/FRRConsultation-Report-Our-Sexual-Future-with-robots_Final.pdf (accessed 6 Sep 2017).

19 Brown RV. UKHL 19, 1 AC 212, 1993.

20 Dautenhahn K. Socially intelligent robots: dimensions of human-robot interaction. Philos Trans R Soc Lond B Biol Sci 2007;362:679-704. 